\title{
Physico-Chemical Analysis of Drinking Water Quality of Arbaminch Town
}

\section{Amanial Haile Reda*}

Department of Chemistry, College of Natural Sciences, Arbaminch University, Arbaminch, Ethiopia

\begin{abstract}
In this study drinking water samples were collected from three sites of Arbaminch town and have been analyzed for some physico-chemical parameters like $\mathrm{pH}$, electrical conductivity (EC), total dissolved solids (TDS), total suspended solids (TSS), total solids (TS), total alkalinity (TA), total hardness (TH), chloride (Cl-) and fluoride (F-). The result showed that $\mathrm{pH}, \mathrm{EC}$, TDS, TSS, TS, TA, TH, Cl- and F- ranged from 7.13 to 7.76, 210.0 to $230.5 \mu \mathrm{Scm}-1,134.4$ to $147.1 \mathrm{mg} / \mathrm{L}$, 11.22 to $15.44 \mathrm{mg} / \mathrm{L}, 145.62$ to $262.45 \mathrm{mg} / \mathrm{L}, 88.6$ to $182.02 \mathrm{mg} / \mathrm{L}, 119.2$ to $135.11 \mathrm{mg} / \mathrm{L}, 135.22$ to $554.46 \mathrm{mg} / \mathrm{L}$ and 2.0 to $4.41 \mathrm{mg} / \mathrm{L}$ respectively. All the measured parameters were within the standard drinking water quality values of WHO except $\mathrm{Cl}$ - content in AMU sampling site and $\mathrm{F}$ - in all sampling sites. The level of $\mathrm{Cl}$ - in Secha and Sikela sampling sites were within the standard value of WHO $(500 \mathrm{mg} / \mathrm{L})$. But the level of $\mathrm{Cl}$ - was found beyond the standard value of WHO in AMU sampling site. Similarly the concentration of F- was found higher than the standard limit value of WHO (1.5 mg/L) in all sampling sites but within the maximum permissible values of US-EPA $(4.0 \mathrm{mg} / \mathrm{L})$ except in the AMU sampling site which is a little bit higher than the US-EPA. In general the present investigation found that the maximum parameters were not at a level of pollution.
\end{abstract}

Keywords: Physico-chemical parameters; Drinking water quality; Water quality standards

\section{Introduction}

Water is one of the most important and most precious natural resources. It is essential in the life of all living organisms from the simplest plant and microorganisms to the most complex living system known as human body. Water a combination of hydrogen and oxygen atoms, with a chemical formula, $\mathrm{H}_{2} \mathrm{O}$ and known to be the most abundant compound (70\%) on earth surface. It is significant due to its unique chemical and physical properties [1-3].

Access to safe drinking water is key to sustainable development and essential to food production, quality health and poverty reduction. Safe drinking water is essential to life and a satisfactory safe supply must be made available to consumers [4]. Water is thus becoming a crucial factor for development and the quality of life in many countries. In individual arid areas it has even become a survival factor [5]. Therefore, water intended for human consumption must not contain pathogen germs or harmful chemicals; because water contaminated with microorganisms is the cause of epidemics [6]. That is good drinking water is not a luxury but one of the most essential requirements of life itself [7]. However, developing countries, like Ethiopia, have suffered from a lack of access to safe drinking water from improved sources and to adequate sanitation services [8]. The WHO [9] revealed that seventy five percent of all diseases in developing countries arise from polluted drinking water.

Therefore; water quality concerns are often the most important component for measuring access to improved water sources. Acceptable quality shows the safety of drinking water in terms of its physical, chemical and bacteriological parameters [10]. International and local agencies have established parameters to determine biological and physicochemical quality of drinking water [11]. The problems associated with chemical constituents of drinking water arise primarily from their ability to cause adverse health effects after prolonged periods of exposure, of particular concern are contaminants that have cumulative toxic properties, such as heavy metals and substances that are carcinogenic [12]. Mahmoud et al. [13] also stated that the most common problems in household water supplies may be attributed to hardness, iron, sulfides, sodium chloride, alkalinity, acidity, and disease-producing pathogens, such as bacteria and viruses. In addition to this IARC [14] and AWA [15] also reported that the use of chemical disinfectants in water treatment or construction materials used in water supply system usually results in the formation of the chemical by-products, some of which are potentially hazardous. This makes drinking water is a vehicle for disease transmission [16].

Therefore, it is desirable to control the intake of these potentially toxic chemicals from drinking water because the intake from other sources which food or air may be difficult to avoid [17]. Like other developing countries drinking water quality is major issue in Ethiopia and studies related to drinking water quality of Arbaminch town have not conducted. Therefore, the aim of this study was to examine the levels of some physico-chemical parameters of drinking water of Arbaminch town.

\section{Materials and Methods}

\section{General description of study area}

Drinking water samples were collected from Arbaminch town which is the administrative and trading center of the Gamogofa zone, located at $505 \mathrm{Km}$ from Addis Ababa, the capital city of Ethiopia and $275 \mathrm{Km}$ south west of Awassa. The total area of the town is estimated about 1095 hectares and it lies at an altitude of 1300 meters above sea level, its average temperature is $29^{\circ} \mathrm{C}$ and the average annual rainfall is $900 \mathrm{~mm}[18]$.

\section{Sample collection}

Drinking water samples were collected from three sampling sites (Secha, Sikela and Arbaminch University main campus (AMU))

*Corresponding author: Amanial Haile Reda, Department of Chemistry, College of Natural Sciences, Arbaminch University, Arbaminch, Ethiopia, Tel: 251913318600; E-mail: manuyehaile@gmail.com

Received February 01, 2016; Accepted February 28, 2016; Published March 03, 2016

Citation: Reda AH (2016) Physico-Chemical Analysis of Drinking Water Quality of Arbaminch Town. J Environ Anal Toxicol 6: 356. doi:10.4172/2161-0525.1000356

Copyright: ( $) 2016$ Reda AH. This is an open-access article distributed under the terms of the Creative Commons Attribution License, which permits unrestricted use, distribution, and reproduction in any medium, provided the original author and source are credited. 
of Arbaminch town. The potable water samples were collected in cleaned plastic polyethylene bottles and brought to the laboratory in an icebox jar to avoid unusual change in water quality. Prior to the sampling all the bottles are washed and rinsed thoroughly with distilled water. Standard methods [19] were followed for sample collection and preservation.

\section{Determination of physico-chemical parameters of drinking water}

Determination of alkalinity using phenolphthalein indicator: To $50 \mathrm{~mL}$ of each of the water samples, 3 drops of phenolphthalein indicator was added. The sample was titrated with $0.02 \mathrm{~N} \mathrm{H}_{2} \mathrm{SO}_{4}$ to $\mathrm{pH}$ 8.3 and phenolphthalein alkalinity was estimated (phenolphthalein indicator was changed color from pink to colorless at $\mathrm{pH} 8.3$ ). Finally the phenolphthalein alkalinity of water was calculated as follows,

Phenolphthalein alkalinity $(\mathbf{m g} / \mathbf{L})$ as $\mathrm{CaCO}_{3}=\frac{\mathrm{A}_{1} \times \mathrm{N} \times 50 \times 1000}{\mathrm{~V}}$

Where $\mathrm{A}_{1}=$ volume of $\mathrm{H}_{2} \mathrm{SO}_{4}$ in $\mathrm{mL}, \mathrm{N}=$ normality of $\mathrm{H}_{2} \mathrm{SO}_{4}$ used to titrate, $\mathrm{V}=$ volume of sample used in $\mathrm{mL}$

Determination of $\mathbf{p H}$ : The $\mathrm{pH}$ of each sample was measured with portable field $\mathrm{pH}$ meter.

Determination of Total Alkalinity (TA): Three drops of bromcresol green indicator was added to $50 \mathrm{~mL}$ of each the samples and titrated with $0.02 \mathrm{~N} \mathrm{H}_{2} \mathrm{SO}_{4}$ to $\mathrm{pH} 4.5$ and total alkalinity was estimated (bromcresol green indicator was changed the color from blue to yellow at $\mathrm{pH} 4.5$ ). Amount of acid used at this moment starting phenolphthalein was used to react with hydroxide, carbonate and bicarbonate and it was constituted of total alkalinity. Finally total alkalinity was calculated as follows.

Total alkalinity $(\mathbf{m g} / \mathrm{L})\left(\right.$ as $\left.\mathrm{CaCO}_{3}\right)=\underline{\mathrm{A}_{2} \times \mathrm{N} \times 50 \times 1000}$

$\mathrm{V}$

$\mathrm{A}_{2}=$ Volume of $\mathrm{H}_{2} \mathrm{SO}_{4}$ consumed in $\mathrm{mL}$ starting from phenolphthalein, $\mathrm{N}=$ normality of $\mathrm{H}_{2} \mathrm{SO}_{4}, \mathrm{~V}=$ volume of sample used in $\mathrm{mL}$.

Determination of Total Dissolved Solid (TDS), Total Suspended Solid (TSS) and Total Solid (TS): For total suspended solid (TSS), $100 \mathrm{ml}$ of the water sample of each was filtered through a pre weighed filtered paper. The filtered papers were dried at $103-105^{\circ} \mathrm{C}$ in oven and TSS was determined by the following formula.

$\operatorname{TSS}(\mathbf{m g} / \mathrm{L})=$ filter post weight - filter pre weight $\times 1000$

\section{V sample $(\mathrm{ml})$}

TDS was measured using combined $\mathrm{pH} / \mathrm{T}^{\circ} / \mathrm{TDS}$ and conductivity meter model 4200 whereas TS was measured from the two parameters of TDS and TSS given by

$$
\mathrm{TS}(\mathrm{mg} / \mathrm{L})=\mathrm{TDS}(\mathrm{mg} / \mathrm{L})+\mathrm{TSS}(\mathrm{mg} / \mathrm{L})
$$

Determination of Electrical Conductivity (EC): EC was measured using combined TDS/conductivity meter model 4200 by shifting one of the four buttons of instrument. Before measuring the probes were rinsed with distill water and purity of distill water was checked. Then the probe was immersed in beaker containing water sample and moved up and down taped on the beaker to be free the electrodes from any bubbles. Then data was recorded for each sample.

Determination of chloride ion: $10 \mathrm{~mL}$ of each water sample was taken in conical flask. And $\mathrm{pH}$ was measured and adjusted in between
7-9. After that $1 \mathrm{~mL}$ of $5 \% \mathrm{~K}_{2} \mathrm{CrO}_{4}$ indicator was added to and titrated with previously standardized silver nitrate solution to brick red color precipitate end point and noted down volume of titrant used as $\mathrm{V}_{1}$. Similarly a blank titration was done by taking $10 \mathrm{~mL}$ of distilled water instead of sample and precedes the same procedure as the sample and recorded the final volume as $\mathrm{V}_{2}$.

Finally the concentration of chloride present in the sample was calculated using the following equation.

$$
\text { Chloride ion concentrations }(\mathrm{mg} / \mathrm{L})=\frac{\left(\mathrm{V}_{1}-\mathrm{V}_{2}\right) \times 35.5 \times 1000}{\text { V sample }}
$$

Where $\mathrm{V}_{1}=$ volume of titrant consumed for water sample. $\mathrm{V}_{2}=$ Volume of titrant consumed for blank, $\mathrm{N}=$ normality of silver nitrate and $\mathrm{V}_{\text {sample }}=$ volume of sample used $(\mathrm{mL})$.

Determination of total hardness of water: To determine the total hardness of water samples $20 \mathrm{~mL}$ of each of the water samples was pipette out in a washed conical flask. $5 \mathrm{~mL}$ ammonia ammonium chloride buffer solution and 2-3 drops of Eriochrome Black-T indicator were added, the color of the solution turns wine red. This solution was titrated against previously standardized EDTA solution taken in the burette until the color changes from wine red to sky blue which indicated the end point. The final reading of the burette was noted and the titration was repeated to get concordant value. Finally using the analytical calculation, total hardness of water sample was determined in terms of $\mathrm{mg} / \mathrm{L}$ of $\mathrm{CaCO}_{3}$.

Potentiometer determination of fluoride: Series of working standard solutions of fluoride were prepared from stock solution of fluoride which is prepared by dissolving $2.21 \mathrm{~g} \mathrm{NaF}$ in a $1000 \mathrm{~mL}$ polystyrene volumetric flask with deionised water. Sodium fluoride has been previously oven dried at $105^{\circ} \mathrm{C}$ for 1 hour and stored in dessicator. Then a series of standard solutions ranged from 0.05 to $10 \mathrm{mg} / \mathrm{L}$ of concentration were prepared by appropriate diluting of the stock solution to obtain a calibration curve. Total ionic strength adjustment buffer (TISAB) was also prepared by taking $58 \mathrm{~g}$ sodium chloride, $30.00 \mathrm{~g}$ of sodium nitrate and $57 \mathrm{~cm}^{3}$ glacial acetic (ethanoic) acid dissolving in $500 \mathrm{~cm}^{3}$ distilled water. Before final dilution $\mathrm{pH}$ value of mixed buffer solution was adjusted to 5.50 with $5 \mathrm{~mol} / \mathrm{dm}^{3}$ of sodium hydroxide solution. After regulating $\mathrm{pH}$ values, received solution was put into $1 \mathrm{dm}^{3}$ measuring glass and filled with distilled water to measurement line.

For the determination of fluoride in the water samples, $25.00 \mathrm{~cm}^{3}$ the prepared TISAB buffer was added to each of the $25 \mathrm{~cm}^{3}$ of water samples and each of the series of standard solutions, the magnetic nucleus was inserted and the string speed was adjusted. Electrode was put in to the solution and after five minute potential was read. Then the standard solution potential was measured, according to which calibration curve was constructed. In every sample the fluoride ion content was measured three times. Similarly the potential of each of the prepared water samples were measured three times (Table 1).

\section{Results and Discussion}

Mean values of the measured physico-chemical parameters of the drinking water samples are shown in Table 2.

\begin{tabular}{|c|c|c|c|}
\hline No. & Parameters & $\begin{array}{c}\text { Concentration of } \\
\text { Standards } \mathbf{( p p m )}\end{array}$ & $\begin{array}{c}\text { Correlation coefficient of } \\
\text { calibration curve } \mathbf{( R}^{\mathbf{2}} \mathbf{)}\end{array}$ \\
\hline $\mathbf{1}$ & $\mathrm{F}^{-}$ & $0.05,0.5,1.0,2,5,5,10$ & 0.988 \\
\hline
\end{tabular}

Table 1: Working standards and correlation coefficient of calibration curve fo fluoride ion. 


\begin{tabular}{|c|c|c|c|c|c|c|}
\hline \multirow[t]{2}{*}{ Parameters } & \multicolumn{3}{|c|}{ Sampling sites } & \multicolumn{2}{|c|}{ BIS standards } & \multirow{2}{*}{$\begin{array}{c}\text { WHO } \\
\text { Standard }\end{array}$} \\
\hline & Secha & Sikela & AMU & $\begin{array}{c}\text { Acceptable } \\
\text { limit }\end{array}$ & Maximum limit & \\
\hline $\mathrm{pH}$ & $7.34 \pm 0.65$ & $7.13 \pm 0.45$ & $7.76 \pm 0.23$ & 6.5-8.5 & $6.5-9.2$ & $6.5-8.5$ \\
\hline TDS & $135.40 \pm 0.01$ & $134.40 \pm 0.05$ & $147.10 \pm 0.06$ & 500 & 2000 & 500 \\
\hline TSS & $12.00 \pm 1.10$ & $11.22 \pm 0.92$ & $15.44 \pm 1.03$ & & & $\leq 30$ \\
\hline TS & $147.40 \pm 0.30$ & $145.62 \pm 0.96$ & $262.45 \pm 0.58$ & & & 500 \\
\hline EC & $211.80 \pm 0.05$ & $210.00 \pm 0.02$ & $230.50 \pm 0.05$ & 300 & - & 400 \\
\hline $\mathrm{TH}$ & $122.34 \pm 1.10$ & $119.20 \pm 1.01$ & $135.11 \pm 0.00$ & 300 & 600 & 500 \\
\hline TA & $88.60 \pm 0.62$ & $92.00 \pm 0.10$ & $181.02 \pm 0.10$ & 200 & 600 & \\
\hline Phenolphthalein alkalinity & ND & ND & ND & & & \\
\hline $\mathrm{Cl}^{-}$ & $135.22 \pm 3.44$ & $136.58 \pm 5.33$ & $554.46 \pm 7.08$ & 200 & 1000 & 250 \\
\hline $\mathrm{F}^{-}$ & $2.00 \pm 0.34$ & $2.05 \pm 0.79$ & $4.42 \pm 1.56$ & & & $1.5,4.0$ * \\
\hline
\end{tabular}

All are in $\mathrm{mg} / \mathrm{L}$ except $\mathrm{pH}$ and $\mathrm{EC}(\mu \mathrm{S} / \mathrm{cm}), \mathrm{ND}=$ not detected, Source; * US-EPA

Table 2: Average concentration (Mean $\pm S D, n=3$ ) values of physico-chemical parameters of drinking water samples and compared with drinking water quality standards (Indian and WHO)

\section{pH}

The $\mathrm{pH}$ is a measure of the hydrogen ion concentration in water. Drinking water with a $\mathrm{pH}$ between 6.5 to 8.5 is generally considered satisfactory. Acid water tend to be corrosive to plumbing and faucets, particularly, if the $\mathrm{pH}$ is below 6 . Alkaline waters are less corrosive; water with a $\mathrm{pH}$ above 8.5 may tend to have a biter or soda-like taste. In this study, the concentration of hydrogen ion $(\mathrm{pH})$ ranges between 7.13 to 7.76 and all the water samples analyzed have concentration within the safe limit of 6.5 to 8.5 standard set by the WHO. Thus indicated that the measured $\mathrm{pH}$ values of the drinking water samples were within permissible value of WHO; which will not cause any harmful effect to the consumers (Figure 1).

\section{Total Suspended Solids (TSS) and Total Solids (TS)}

Regarding the values of TSS, all the water samples showed less presence of contaminants, as the values ranged from $11.22 \mathrm{mg} / \mathrm{L}$ to $15.44 \mathrm{mg} / \mathrm{L}$. And all these measured values were within the permissible limits of WHO $(\leq 30 \mathrm{mg} / \mathrm{L})$. Similarly the TS values of water samples were ranging from 145.62 to $262.45 \mathrm{mg} / \mathrm{L}$ and all these measured values were also within the WHO guide line value which is $500 \mathrm{mg} / \mathrm{L}$. The results of both TSS and TS showed that the drinking water doesn't cause health problem to the consumers.

\section{Total Dissolved Solids (TDS)}

TDS can be taken as an indicator for the general water quality because it directly affects the aesthetic value of the water by increasing turbidity. High concentrations of TDS limit the suitability of water as a drinking source and irrigation supply. The acceptable range of TDS is $500 \mathrm{mg} / \mathrm{L}$. In the present study the range of TDS of analyzed water samples varied between 134.4 to $147.1 \mathrm{mg} / \mathrm{L}$ as shown in Table 2. The highest TDS value was observed at AMU and this might be due to the difference in their source as the source of AMU is underground water where as the source of Secha and Sikela is spring water. However; all the values were within the standard limit of WHO $(500 \mathrm{mg} / \mathrm{L})$. Therefore the drinking water is safe in terms of TDS (Figure 2).

\section{Electrical Conductivity (EC)}

The ability of a solution to conduct an electrical current is governed by the migration of solutions and is dependent on the nature and numbers of the ionic species in that solution. This property is called electrical conductivity. It is a useful tool to assess the purity of water. The permissible limit for electrical conductivity (EC) is $300 \mu \mathrm{S} \mathrm{cm}$ $\mathrm{EC}$ of the collected samples ranged from 210.0 to $230.5 \mu \mathrm{S} \mathrm{cm}^{-1}$. This showed that the EC values of all water samples were within permissible limits and the potable water is safe in terms of EC (Figure 3).

\section{Total Alkalinity (TA) and Phenolphthalein alkalinity}

Alkalinity of water is its acid neutralizing capacity. The alkalinity of groundwater is mainly due to carbonates and bicarbonates. The acceptable limit of alkalinity is $200 \mathrm{mg} / \mathrm{L}$ and in the absence of alternate water source, alkalinity up to $600 \mathrm{mg} / \mathrm{L}$ is acceptable for drinking. In the present study alkalinity with phenolphthalein indicator and alkalinity with bromcresol indicator (total alkalinity) were determined and the results showed that the total alkalinity of the water samples ranged from 88.6 to $182.02 \mathrm{mg} / \mathrm{L}$. But alkalinity with phenolphthalein indicator was zero in all sampling sites. According to BIS (Indian standards of drinking water) the desired limit and the maximum permissible limit for alkalinity in drinking water is 200 and $600 \mathrm{mg} / \mathrm{L}$ respectively. In the present study; the value of total alkalinity content in all sampling sites has been found within the desired limit and maximum permissible limit of BIS.

\section{Total hardness (TH)}

In groundwater hardness is mainly contributed by bicarbonates, carbonates, sulphates and chlorides of calcium and magnesium. So, the principal hardness causing ions are calcium and magnesium. The acceptable limit of total hardness is $300 \mathrm{mg} / \mathrm{L}$ whereas the maximum limit is $600 \mathrm{mg} / \mathrm{L}$. The hardness of analyzed water samples varied from 119.20 to $135.11 \mathrm{mg} / \mathrm{L}$ as $\mathrm{CaCO}_{3}$. The highest value of total hardness was observed at AMU sampling site, as shown in Table 1. Durfor et al. [20] have classified water as soft, moderate, hard and very hard as given in Table 3. As per this classification most of the samples comes under moderate to hard category. On the basis of this classification it has been observed that no water samples are soft but all the measured values were within the acceptable limit values of BIS $(300 \mathrm{mg} / \mathrm{L})$ and WHO (500 mg/L).

\section{Chloride}

The concentration of chloride is the indicator of sewage pollution and also imparts laxative effect. Atmospheric sources or sea water contamination is reason for bulk of the chloride concentration in groundwater which may exceed due to base-exchange phenomena, high temperature, domestic effluents, septic tanks and low rainfall [21]. Porosity soil and permeability also plays a key role in building up the chlorides concentration [22]. The chloride content of studied water samples were within permissible limit of $250 \mathrm{mg} / \mathrm{L}$ prescribed 
Citation: Reda AH (2016) Physico-Chemical Analysis of Drinking Water Quality of Arbaminch Town. J Environ Anal Toxicol 6: 356. doi:10.4172/21610525.1000356

Page 4 of 5

by [23]. In present study, the results of chlorides in all sampling sites ranged from 135.22 to $554.46 \mathrm{mg} / \mathrm{L}$. The chloride level recorded in Secha and Sikela sampling sites were within the drinking water quality of WHO $(250 \mathrm{mg} / \mathrm{L})$ and acceptable limit of BIS $(200 \mathrm{mg} / \mathrm{L})$ where as the chloride level recorded in AMU site was higher than the acceptable limit value of BIS $(200 \mathrm{mg} / \mathrm{L})$ and WHO $(250 \mathrm{mg} / \mathrm{L})$, but it was within the maximum limit of BIS (1000 mg/L).

\section{Fluoride}

In this study the measured value of $\mathrm{F}^{-}$ion of the water samples were ranged from 2.00 to $4.42 \mathrm{mg} / \mathrm{L}$. The measured value of $\mathrm{F}^{-}$in AMU sampling site was higher as compared to the levels of $\mathrm{F}^{-}$obtained from Secha and Sikela sampling sites and thus higher value might be due to the presence of fluoride compounds like $\mathrm{CaF}_{2}, \mathrm{Na}_{3} \mathrm{AlF}_{6}$ and $\mathrm{Ca}_{5}\left(\mathrm{PO}_{4}\right)_{3} \mathrm{~F}$ in the underground water. In addition to this the measured value of $\mathrm{F}^{-}$in AMU sampling site was above the standard values of $\mathrm{F}^{-}$ion in drinking water set by WHO which is $1.5 \mathrm{mg} / \mathrm{L}$ and US-EPA $(4 \mathrm{mg} / \mathrm{L})$ but the rests were within the maximum standard value of $\mathrm{F}^{-}$in drinking water set by US-EPA but above the WHO (1.5 mg/L) (Figure 4).

\begin{tabular}{|c|c|}
\hline Total hardness $\mathbf{( m g / L )}$ & Nature of water \\
\hline $0-60$ & Soft \\
\hline $61-120$ & Moderate \\
\hline $121-180$ & Hard \\
$>181$ & Very \\
\hline
\end{tabular}

Table 3: Classification of water on the basis of total hardness [20]

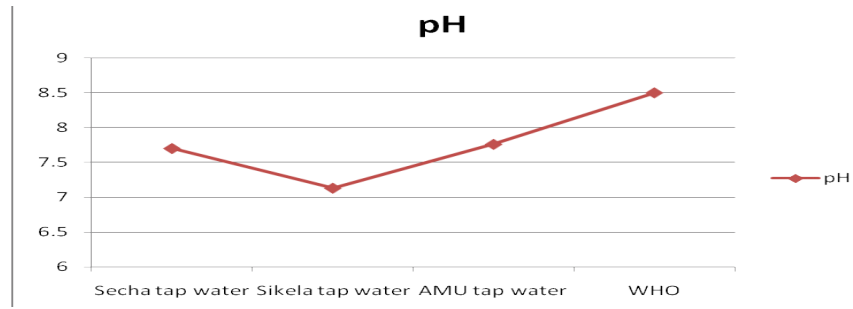

Figure 1: $\mathrm{pH}$ values of various water samples.

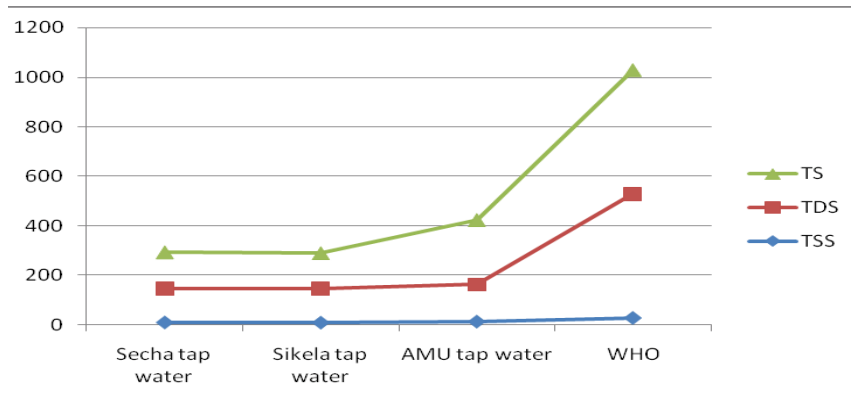

Figure 2: TS, TDS and TSS values of various water samples (all are in $\mathrm{mg} / \mathrm{L}$ )

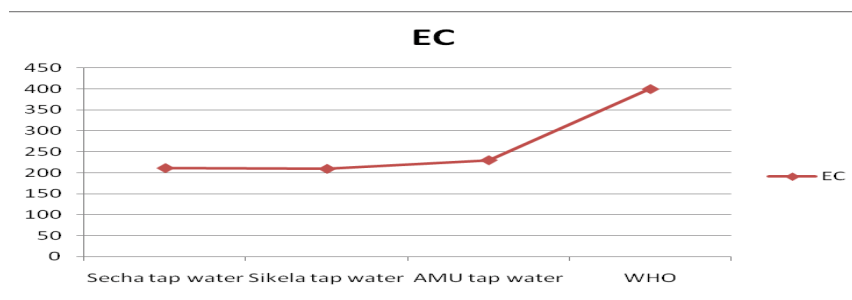

Figure 3: EC values of various water samples in $\mu \mathrm{S} \mathrm{cm}^{-1}$.

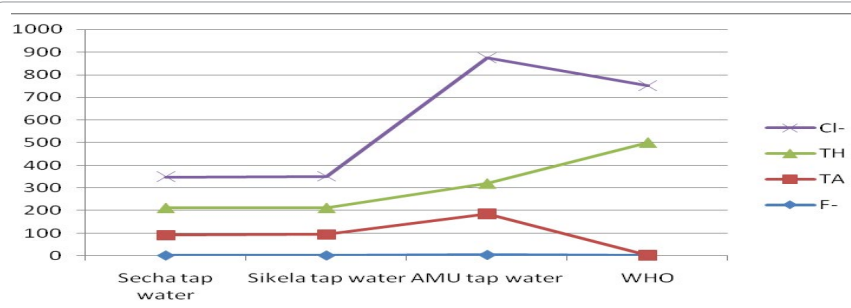

Figure 4: $\mathrm{F}^{-}, \mathrm{TA}, \mathrm{TH}$ and $\mathrm{Cl}^{-}$values of various water samples (all are in $\mathrm{mg} / \mathrm{L}$ ).

\section{Conclusion}

In this study the collected drinking water samples of Arbaminch town were analyzed for physicochemical parameters of $\mathrm{pH}, \mathrm{EC}$, TDS, TSS, TS, TA, TH, $\mathrm{Cl}^{-}$and $\mathrm{F}^{-}$. The result revealed that almost all the measured parameters were within the standard drinking water quality given by WHO, BIS and US-EPA. But the concentration of $\mathrm{F}^{-}$in all sampling sites was found a little bit higher than standard value of WHO, but within the maximum permissible limit given by the USEPA except AMU sampling site. In addition to this the level of $\mathrm{Cl}^{-}$in AMU sampling site was also found higher than the WHO guideline but within the maximum permissible limit of BIS. In general the present investigation found that the maximum parameters were not at a level of pollution and may not cause harmful effect to the consumers.

\section{Acknowledgements}

The author acknowledge to Arbaminch University department of chemistry for supporting necessary materials during the analysis.

\section{References}

1. Onifade AK, Ilori RM (2008) Microbiological analysis of sachet water vended in Ondo state, Nigeria. Environ Res J 2: 107-110.

2. Osci Y (2005) New School Chemistry for Senior Secondary Schools. African First Publisher Ltd, Onitsha. 3rd edn., p: 292.

3. Obi CN, Okocha CO (2007) Microbiological and physicochemical analysis of selected borehole waters. Journals of enginery applied science 257: 920-929.

4. Ackah M, Anim AK, Gyamfi ET, Acquah J, Nyarko ES, et al. (2012) Assessment of the quality of sachet water consumed in urban townships of Ghana using physico-chemical indicators: A preliminary study. Advances in Applied Science Research 3: 2120-2127.

5. Eddy NO, Ekop AS (2007) Assessment of the quality of water treated and distributed by the Akwa Ibom state water company. E-Journal of Chemistry 4: $180-186$.

6. Balbus JM, Embrey MA (2002) Risk factors for waterborne enteric infections Curr Opin Gastroenterol 18: 46-50.

7. Ajewole G (2005) Water. An overview. Nigeria institute of food science and technology, Nigeria 2: 4-15

8. WHO (2006) In Water, Sanitation and Health World Health Organization

9. WHO (2000) Disinfectants and disinfectant by products. Environmental health criteria 216, Geneva: world health organization.

10. WHO (2004) Guidelines for Drinking-water Quality. Geneva: World Health Organization.

11. Havelaar A, Blumenthal UJ, Strauss M, Kay D, Bartram J (2001) Guidelines: the current position. Water quality: Guidelines, Standards and Health. pp: 1742 .

12. Department of the Environment, Welsh Office (DEWO) (1989) Guidance and safeguarding the quality of public water suppliers. Her Majesty's Stationery Office London.

13. Saleh MA, Emmanuel E, Joseph J, Wilson BL (2001) Chemical evaluation of commercial bottled drinking water from Egypt. Journal of Food composition and Analysis 127-152. 
Citation: Reda AH (2016) Physico-Chemical Analysis of Drinking Water Quality of Arbaminch Town. J Environ Anal Toxicol 6: 356. doi:10.4172/21610525.1000356

14. [No authors listed] (1987) Overall evaluations of carcinogenicity: an updating of IARC Monographs volumes 1 to 42. IARC Monogr Eval Carcinog Risks Hum Suppl 7: 1-440.

15. American Water works Association (AWA) (1991) Health effect of disinfectants and disinfection by products. Denver Co., New York, pp: 86-98.

16. Degremont J (1991) Water treatment handbook. Lavoisier, Paris, pp: 10-15.

17. Danish W (2003) Technical support document on drinking water standard objectives and guide lines.

18. SNNPRPIP (2008) The southern nations, nationalities and peoples' regional state resource potential and investment opportunities, Awassa.
19. APHA (2005) Standard methods for the examination of water and waste water Washington, DC: American Public Health Association.

20. Durfor CN, Becker E (1964) Public water supplies of the 100 largest cities in the United States. In Geological Survey Water-Supply, US Government Printing Office, Washington, 1812, p: 364

21. Venkateswara BR (2011) Physicochemical analysis of selected ground water samples of Vijayawada rural and urban in Krishna district, Andhra Pradesh, India. International Journal of Environmental Sciences 2: 710-714.

22. Chanda DK (1999) Hydrology Journal 7: 431-439.

23. Arghyam (1991) Indian Standards for Drinking Water. Bureau of Indian Standards, New Delhi, India, IS: 10500. 